\title{
The evaluation of sustainable development for the manufacturers of construction-polymer products
}

\author{
Nailya Gareeva $^{1 *}$, Anna Starodubova ${ }^{2}$, and Anna Romanova ${ }^{3[0000-0002-4614-0872] ~}$ \\ ${ }^{1}$ Kazan Innovative University named after V.G. Timiryasov, 423570, Nizhnekamsk, Russia \\ ${ }^{2}$ Kazan National Research Technological University, 420015, Kazan, Russia \\ ${ }^{3}$ Kazan State University of Architecture and Engineering, 420015, Kazan, Russia
}

\begin{abstract}
The authors studied the indicators that impacted on the sustainable development of industrial enterprises and developed the comprehensive method for their evaluation. This methodology consists of 4 stages: data collection, evaluation of indicators, identification of deviations from the principles of sustainable development, recommendations for adjusting the business model and the network structure of cooperation. A scoring evaluation of the indicators of sustainable development for enterprises is proposed. The authors selected 12 indicators and grouped them according to the economic, environmental and social principles of sustainable development. The study identified seven classes of sustainability for enterprises and their characteristics. If enterprises had higher score, it meant they had higher class and higher sustainability, and vice versa. The method was tested on the example of the evaluation of production of construction-polymer products for 2020. The proposed methodology will enable enterprises to independently evaluate the level of sustainable development. It will also show deviations from the norm separately for each principle of sustainable development. The perspective of this study is that it is possible to develop recommendations for each class of sustainable development.
\end{abstract}

Keywords. Sustainable development, business model, constructionpolymer product, cooperation, lean concept.

\section{Introduction}

The report «Chemical Industry 4.0. The development of innovation in the era of change» of «Deloitte» indicates 30 trends, which will play a key role in plastics production until 2030. Most of these trends are related to the principles of sustainable development. Therefore, taking into account new tendencies, enterprises are now facing the tasks of reformatting production and search for new business models. So these changes for the manufacturers of construction-polymer products open up new growth possibilities.

At present, there are no universal methodologies for evaluation sustainable development that can be used by all companies, regardless of their size and activities. The results of this evaluation are necessary for the future expansion of cooperation in the production of

*Corresponding author: gareevana5@mail.ru 
construction-polymer products within the industry and between different industries. There is therefore a need to adopt best practices for evaluation sustainable development and to develop tools for evaluating business models on sustainable development criteria.

The object of the paper is to study the factors relating the sustainable development of industrial enterprises and to develop an integrated method for their evaluation.

The subject of the study is indicators of the level of sustainable development for the enterprises of construction-polymer products.

The study supports the hypothesis that the sustainable development class depends on economic, social and environmental factors in any enterprise. Each of these factors has an impact on sustainable development in the short or long term.

A literary review confirmed the relevance of the selected research topic.

D. Gligor, C. N. Jurcut believe that the involvement of entrepreneurs in sustainable development associations affects their competitiveness [1]. Some experts felt that there was a need to develop the region's competitiveness through sustainable development [2-8].

B. Derqui believes that Industry needs to prepare detailed sustainability reports to enhance transparency and credibility of information. In his view, the evaluation of sustainability development of enterprises posed a problem of the measurement of results [9].

Since 2018, the European Union has made non-financial reporting mandatory for enterprises operating in its territory (according to Directive 2014/95/EU) [10].

The Organisation for Economic Cooperation and Development (OECD) has developed a sustainable development approach to investment policy [11].

The UN Trade and Development Commission (UNCTAD) develops indicators for reporting on sustainable development goals for enterprises [12].

Exchange Guidance and Recommendations on Sustainability of the World Federation of Exchanges proposed a methodology for calculating financial indicators for evaluating climate risks [13].

SASB standards have now been developed for the disclosure of information on sustainable development indicators for 79 industries [14].

GRI published Business Reporting on the SDGs: An Analysis of the Goals and Targets [15].

The Climate Action 100+ Association was created specifically to monitor the reporting of the 161 largest companies in the world. This monitoring is necessary to observe the implementation of the Paris Climate Agreement [16].

R. Baumgarther and D. Ebner noted that most enterprises do not have a clear sustainable development strategy. It suggests that these enterprises are accidentally concerned with sustainability issues [17]. According to these authors, corporate sustainability is affected by both internal and external factors. Corporate sustainability has a positive impact on society in the long term [17]. These researchers proposed a classification of strategies for sustainable enterprise development. It includes an introverted, extruded, conservative, visionary strategy [17].

E. Melnikova, Y. Bezrukikh classified business models according to their ability to manage sustainable development. The authors proposed three types of enterprise resilience: static, dynamic and structural [18].

W. Gu, X. Zheng proposed three types of relationship between environmental pollution and enterprise income levels. This evaluation is based on the S. Kuznets environmental model [19].

I. Barletta, M. Despeisse, S. Hoffenson and B. Johansson, I.D. Meza-Ruiz, L. RochaLona, M. del Rocío Soto-Flores, J.A.Garza-Reyes, V. Kumar, G. Lopez-Torres suggested that the level of enterprise readiness for sustainable development should be determined [20, 21].

K.S. Sangwan, V. Bhakar and A.K. Digalwar proposed an integrated enterprise sustainability evaluation system (using the example of the auto industry) [22].

V. Koksharov, N. Starodubets, M. Ponomareva proposed indicators to evaluate the sustainability of an industrial enterprise based on indicators of the circular economy [23]. J. Donovan, Ch. Topple, E. Masli, T. Vanichseni gave an assessment of corporate sustainability 
in Thailand [24]. E. Molina-Sanchez, J. Leyva-Diaz, F. Cortes-Garcia, V. Molina-Moreno proposed sustainable development indicators for waste management based on indicators of the circular economy. These indicators were tested on the example of the paper industry [25].

F. Bassi and J. Dias in their study identified four types of sustainable development of small and medium-sized enterprises based on indicators of the circular economy:

- the enterprises where the circular economy is not introduced;

- the enterprises where a circular economy is to be introduced;

- the enterprises in which all known (universal) solutions of the circular economy are introduced;

- the enterprises where special solutions of the circular economy are introduced [26].

Lopin Kuo, Bao-Guang Chang considered the financial implications for Chinese enterprises of posting information on their sustainability and circular economy [27].

Authors H. Xu, Q. Mei, F. Shahzad, S. Liu, X. Long, J. Zhang analyzed the relationship between green finance and eco-efficiency of enterprises [28].

M. Miralles-Quiros, J. Miralles-Quiros, I. Arraiano studied the relationship between enterprise leadership in sustainable development and the size of the Dow Jones Sustainability Index (DJSI) [29]. M. Yu, R. Zhao considered the relevance and feasibility of DJSI as a comprehensive measure of enterprise sustainability [30]. Works by authors such as Romanova, A., Evgeniya I. and Mironova M., Romanova A., Ilina E., Galeeva I., Egorov D. and Akhmetova A. are devoted to sustainable development [31-32].

\section{Materials and methods}

The study consisted of the following 4 stages.

The first phase of the study proposed an algorithm for evaluating the sustainability of the enterprise. The indicators have been selected to show each goal of sustainable development for enterprise. It was done through expert judgement.

In the second phase of the study, the criteria for each indicator were defined for scoring.

In the third stage, a classification of the levels of sustainability of an enterprise for each group of goals was developed. Thresholds were calculated for each goal and level of sustainability for this classification.

In the fourth stage of the study, a classification of enterprises according to their level of sustainability was developed. The classification was based on the method of grouping data from the third phase of the study.

\section{Results}

The first phase of the study proposed an algorithm for evaluating the sustainability of the enterprise. This methodology consists of several stages: data collection, evaluation of indicators, identification of deviations from the principles of sustainable development, recommendations for adjusting the business model and the network structure of cooperation.

The authors selected the indicators to evaluate the sustainability of the enterprise. These indicators have been chosen on the basis of the following sustainable development goals to be implemented by enterprises:

- «Clean water and sanitation»;

- «Affordable and clean energy»;

- «Decent work and economic growth»;

- «Industry, Innovation, and Infrastructur»;

- «Responsible consumption and production»;

- «Climate action»; 
- «Life below water»;

- «Life on land».

All the goals proposed above have been divided into three groups : economic, social and environmental.

Further, the authors identified indicators for each sustainable development goal in the enterprise (table 1).

Table 1. Indicators and criteria for evaluating sustainable enterprise development.

\begin{tabular}{|c|c|c|c|}
\hline \multirow{2}{*}{ Name of indicator or goals } & \multirow{2}{*}{$\begin{array}{l}\text { specific } \\
\text { weight of the } \\
\text { indicator, } \%\end{array}$} & \multicolumn{2}{|c|}{ Indicator in points } \\
\hline & & maximum & minimum \\
\hline Economic goals: & 10.5 & 10.5 & 0 \\
\hline average revenue in the enterprise & 10.5 & 10.5 & 0 \\
\hline Social goals: & 10.5 & 10.5 & 0 \\
\hline $\begin{array}{l}\text { average number of employees in the } \\
\text { enterprise }\end{array}$ & 5.25 & 5.25 & 0 \\
\hline average wage per 1 staff & 5.25 & 5.25 & 0 \\
\hline Environmental goals : & 79.0 & 79.0 & 0 \\
\hline $\begin{array}{l}\text { class of the working conditions in } \\
\text { the enterprise }\end{array}$ & 7.9 & 7.9 & 0 \\
\hline $\begin{array}{l}\text { waste hazard class for finished } \\
\text { produce and packaging }\end{array}$ & 7.9 & 7.9 & 0 \\
\hline $\begin{array}{l}\text { environmental duty rate for } 1 \text { tonne } \\
\text { of finished products and packaging }\end{array}$ & 7.9 & 7.9 & 0 \\
\hline $\begin{array}{l}\text { recyclability of materials for } \\
\text { production and packaging, release of } \\
\text { harmful substances and possibility of } \\
\text { processing / biodegradation }\end{array}$ & 7.9 & 7.9 & 0 \\
\hline $\begin{array}{l}\text { energy intensity and purity of energy } \\
\text { sources }\end{array}$ & 7.9 & 7.9 & 0 \\
\hline $\begin{array}{l}\text { level of applied advanced } \\
\text { technologies in production }\end{array}$ & 7.9 & 7.9 & 0 \\
\hline $\begin{array}{l}\text { level of environmental pollution in } \\
\text { the production process }\end{array}$ & 7.9 & 7.9 & 0 \\
\hline $\begin{array}{l}\text { age of consumer use of product } \\
\text { /reusability and return of packaging }\end{array}$ & 7.9 & 7.9 & 0 \\
\hline level of loss by LEAN concept & 7.9 & 7.9 & 0 \\
\hline Total & 100.0 & 100.0 & 0 \\
\hline
\end{tabular}

In the second phase of the study, the criteria were established to score each indicator from the first phase of the study.

The weight of each group and indicator was calculated for this purpose. The weights were calculated according to the number of sustainable development goals in each group (100\% for the 8 goals).

The authors established a minimum and maximum threshold for each sustainable development indicator. The size of the threshold is based on the specific weight of each indicator.

In the third stage of the study, a gradation of levels of sustainable development of the enterprise for each group of goals was proposed (table 2). 
Table 2. Levels of sustainable enterprise development.

\begin{tabular}{|l|c|c|c|}
\hline \multirow{2}{*}{$\begin{array}{c}\text { Levels for goals of } \\
\text { sustainable development }\end{array}$} & \multicolumn{3}{|c|}{ Symbol of sustainable development goals } \\
\cline { 2 - 4 } & Economic & Social & Environmental \\
\hline High & F & S & E \\
\hline Average & f & s & e \\
\hline Insufficient & - & - & - \\
\hline
\end{tabular}

In this phase of the study thresholds were calculated for each level of sustainable development as well (fig. 1).

\begin{tabular}{|c|c|c|c|}
\hline $\begin{array}{c}\text { Levels for goals of } \\
\text { sustainable } \\
\text { development }\end{array}$ & \multicolumn{3}{|c|}{ Indicators for goal in points } \\
\hline High & $7.1-10.5$ & $7.1-10.5$ & $52.67-79$ \\
\hline Average & $3.6-7$ & $3.6-7$ & $26.34-52.66$ \\
\hline Insufficient & $0-3.5$ & $0-3.5$ & $0-26.33$ \\
\hline \multirow{2}{*}{} & Economic & Social & Environmental \\
\cline { 2 - 4 } & \multicolumn{3}{|c|}{ Sustainable development goals } \\
\cline { 2 - 4 }
\end{tabular}

Fig. 1. Classification of enterprise stability levels.

This was made possible by calculating minimum and maximum scores for all sustainable development goals based on table 1 data. The higher the score the enterprise gets, the more sustainable its production and vice versa.

In the fourth phase of the study, the authors developed a classification of enterprises by the level of sustainable development. It consists of the classes described below. If an enterprise is of the highest class, it is more sustainable and vice versa.

If the level of sustainable development is insufficient for all three groups of goals, the enterprise is assigned a 0 -class.

An enterprise belongs to the 1 st class if it has an average level of sustainable development for one group of goals and an insufficient level of sustainable development for two groups of goals.

An enterprise belongs to the $2^{\text {nd }}$ class if it has an average level of sustainable development for two groups of goals and an insufficient level of sustainable development for one group of goals.

An enterprise belongs to the 3 rd class if it has an average level of sustainable development in three groups of goals.

An enterprise belongs to the 4th class if it has a high level of sustainable development for one group of goals and an average level of sustainable development for two groups of goals.

An enterprise belongs to the 5th class if it has a high level of sustainable development for two groups of goals and an average level of sustainable development for one group of goals.

If an enterprise has a high level of sustainable development in all three groups of goals, then it belongs to the $6^{\text {th }}$ class.

\section{Discussions}

The method of sustainable development evaluation was tested on the manufacturers of construction-polymer products for 2020 .

The scores of sustainable development for the manufactures of construction-polymer products were calculated on the basis of the criteria (table 3 ). 
Table 3. Evaluation of sustainable development of the manufactures of construction-polymer products for 2020 .

\begin{tabular}{|l|r|r|r|}
\hline \multirow{2}{*}{ Name of indicator or goals } & \multicolumn{3}{c|}{ Indicator in points } \\
\cline { 2 - 4 } & Actual & \multicolumn{1}{|c|}{ Maximum } & \multicolumn{1}{c|}{ Deviation } \\
\hline Economic goals: & 1.43 & 10.5 & -9.07 \\
\hline average revenue in the enterprise & 1.43 & 10.5 & -9.07 \\
\hline Social goals: & 6.56 & 10.5 & -3.94 \\
\hline average number of employees in the enterprise & 1.31 & 5.25 & -3.94 \\
\hline average wage per 1 staff & 5.25 & 5.25 & - \\
\hline Environmental goals: & 37.34 & 79.0 & -41.66 \\
\hline class of the working conditions in the enterprise & 6.91 & 7.9 & -0.99 \\
\hline $\begin{array}{l}\text { waste hazard class for finished produce and } \\
\text { packaging }\end{array}$ & 7.9 & 7.9 & - \\
\hline $\begin{array}{l}\text { environmental duty rate for 1 tonne of finished } \\
\text { products and packaging }\end{array}$ & 7.14 & 7.9 & -0.76 \\
\hline $\begin{array}{l}\text { recyclability of materials for production and } \\
\text { packaging, release of harmful substances and } \\
\text { possibility of processing / biodegradation }\end{array}$ & 1.3 & 7.9 & -6.6 \\
\hline energy intensity and purity of energy sources & 1.98 & 7.9 & -5.92 \\
\hline $\begin{array}{l}\text { level of applied advanced technologies in } \\
\text { production }\end{array}$ & 1.58 & 7.9 & -6.32 \\
\hline $\begin{array}{l}\text { level of environmental pollution in the } \\
\text { production process }\end{array}$ & 6.58 & 7.9 & -1.32 \\
\hline $\begin{array}{l}\text { age of consumer use of product /reusability and } \\
\text { return of packaging }\end{array}$ & 3.95 & 7.9 & -3.95 \\
\hline level of loss by LEAN concept & 0 & 7.9 & -7.9 \\
\hline Total & 45.33 & 100.0 & -54.67 \\
\hline
\end{tabular}

The deviations found from the established maximum for sustainable development can be used to propose activities to improve business models of construction-polymer products.

Fig. 2 shows the level of sustainable development for construction-polymer production in 2020 .

\begin{tabular}{|l|c|c|c|}
\hline \multirow{2}{*}{$\begin{array}{c}\text { Levels for goals of } \\
\text { sustainable } \\
\text { development }\end{array}$} & \multicolumn{3}{|c|}{ Sustainable development goals, points (45.33) } \\
\cline { 2 - 4 } & Economic (1.43) & Social (6.56) & $\begin{array}{c}\text { Environmental } \\
(37.34)\end{array}$ \\
\hline High & & & $\mathrm{e}$ \\
\hline Average & - & $\mathrm{s}$ & \\
\hline Insufficient & & & \\
\hline
\end{tabular}

Fig. 2. Level of sustainability for construction-polymer products for 2020.

These enterprises had the 2-nd class of sustainable development because they received 45.33 out of 100 possible points. Based on fig. 2 data, these enterprises need to develop primarily the economic goals of sustainable development. The authors therefore propose the following activities for these enterprises. These include the establishment of product distribution channels, the development of new market segments, the creation of value propositions for clients.

Only when an economic goal is achieved it will be necessary to develop the environmental, social and sustainable development goals of these enterprises. In our view, it is possible to propose an increase in the number of jobs in these enterprises as a measure to achieve the social goals of sustainable development.

We offer several measures to achieve environmental goals at the the manufacturers of construction-polymer products products. The first step is to reduce losses according to the 
«Lean» concept to lower production cost. The following measures are to increase the level of renewable materials for products and packaging, to reduce the release of harmful substances by them. Enterprises should investigate the possibilities of processing or biodegrading packaging materials and products. Enterprises also face the challenge of raising the level of advanced technology to produce their products.

As a result of the above activities, adjustments in business models of enterprises are required to enhance sustainable development. A new cooperation system in the production of construction-polymer products is also needed for synergistic effect.

Thus, the hypothesis put forward by the authors that, in any enterprise, the sustainable development class depends on economic, social and environmental factors was confirmed. The economic factors of sustainable development operate in the short term. The social and environmental factors of sustainable development work in the long term. This is confirmed by the calculated evaluation of sustainability of production of construction-polymer products. At present, the conditions for achieving sustainable development are not complete, because there is no effective cooperation among all participants directly or indirectly related to the production of construction-polymer products. For this requires the activation of the role of other participants in sustainable development.

\section{Conclusions}

The scientific novelty of the study is the development of an author's methodology based on the scoring of the indicators of sustainable enterprise development. The authors selected 12 indicators, by sustainable development goal group (economic, environmental, and social). The authors proposed the classification of sustainability levels for enterprises and their characteristics. It is possible to determine the level of sustainable development at scores.

The practical significance of the study is determined by the proposed methodology which will allow enterprises to independently assess the level of sustainability (regardless of the size of the enterprise). It will also show deviations for each sustainable development goal in the enterprise.

The enterprises for production of construction-polymer products were assigned to the 2nd class in 2020. That is, they had an average level of sustainable development in terms of environmental and social goals and an insufficient level of sustainable development in terms of economic goals. In order to solve these problems, enterprises need to achieve synergistic effects by developing a new system of cooperation in the production of construction-polymer products.

The perspective of this study is to further explore risks and opportunities (recommendations) for each of the seven identified sustainable development classes.

\section{References}

1. D. Gligor, C. Jurcut. About competitiveness in the context of sustainable development, International management conference Management challenges for sustainable development, Bucharest, Romania, 65-74 (2014).

2. S. Bobylev, S. Solovyeva. Sustainable development goals for the future of Russia, Studies on Russian Economic Development 3 (28), 259-265 (2017).

3. S. Bobylev, Sustainable development: Paradigm for the future, World Economy and International Relations 3 (61), 107-113 (2017).

4. N. Gareeva, A. Starodubova, A. Romanova. The region's competitiveness assessment on the basis of «Sustainable development» concept, IOP Conference series: materials science and engineering 890, (2020). 
5. M. Peris-Ortiz, J. Ferreira, L.N. Farinha. Fernandes Multiple helix ecosystems for sustainable competitiveness, Springer International Publishing Switzerland 184, (2016).

6. E. Doyle, M. Perez-Alaniz. From the concept to the measurement of sustainable competitiveness: social and environmental aspect, Entrepreneurial business and economics review 4 (5), 35-59 (2017).

7. S. Cvetanovic, D. Despotovic, L. Zivkovic, V. Nedic. Environmental dimension of sustainable competitiveness of Serbia and selected European countries, Bulgarian journal of agricultural science 4 (20), 767-778 (2014).

8. D. Zaynullina. The impact of the implementation of an innovative project on the effects arising in the internal and external environment, IOP Conference series: materials science and engineering 890, (2020).

9. B. Derqui. Towards sustainable development: Evolution of corporate sustainability in multinational firms, Corporate Social Responsibility and Environmental Management 27 (6), 2712-2723 (2020).

10. Directive 2014/95/EU. Available at: https:/eur-lex.europa.eu/legal-content/EN/TXT/ ?uri=CELEX\%3A32014L0095.

11. OECD, Policy Framework for Investment. Available at: https://www.oecd.org/daf/inv/ investment-policy/Policy-Framework-for-Investment-2015-CMIN2015-5.pdf (2015).

12. UNCTAD. Available at: https://unctad.org/system/files/official-document/ciiisard81_ru.pdf.

13. Exchange Guidance and Recommendations on Sustainability the World Federation of Exchanges. Available at: https://www.world-exchanges.org/storage/app/media/research/ Studies_Reports/WFE\%20ESG\%20Recommendation\%20Guidance\%20and\%20Metrics $\% 20$ Oct $\% 202015$.pdf.

14. The Sustainability Accounting Standards Board. Available at: https://www.sasb.org/.

15. Business Reporting on the SDGs: An Analysis of the Goals and Targets. Available at: https://d306pr3pise04h.cloudfront.net/docs/publications\%2FGRI_UNGC_SDG_Reporti ng_An_Analysis_of_Goals_and_Targets_2017.pdf.

16. Climate Action 100+. Available at: https://www.climateaction100.org.

17. R. Baumgarther, D. Ebner. Corporate sustainability strategies: sustainability profiles and maturity levels, Sustainable development 18, 76-89 (2010).

18. E. Melnikova, Y. Bezrukikh. Business model of industrial enterprise: Sustainability assessment, IBIMA Conference, 2988-3001 (2017).

19. W. Gu, X. Zheng. An empirical study on the impact of sustainable entrepreneurship: base on the environmental Kuznets model, Journal of business research 123, 613-624 (2021).

20. I. Barletta, M. Despeisse, S. Hoffenson, B. Johansson. Organizational sustainability readiness: A model and assessment tool for manufacturing companies, Journal of Cleaner Production 284, (2021).

21. I.D. Meza-Ruiz, L. Rocha-Lona, M. del Rocío Soto-Flores, J.A. Garza-Reyes, V. Kumar, G.C. Lopez-Torres. Measuring Business Sustainability Maturity-levels and Best Practices, Procedia Manufacturing 11, 751-759 (2017).

22. K.S. Sangwan, V. Bhakar, A.K. Digalwar. Sustainability assessment in manufacturing organizations: Development of assessment models, Benchmarking: An International journal 25 (3), 994-1027 (2018).

23. V. Koksharov, N. Starodubets, M. Ponomareva. Assessment of an enterprise circular economy development, WSEAS Transactions on Business and Economics 16, 559-567 (2019).

24. J. Donovan, Ch. Topple, E. Masli, T. Vanichseni. Corporate Sustainability Assessments: Sustainability practices of multinational enterprises in Thailand, London, (2016).

25. E. Molina-Sanchez, J. Leyva-Diaz, F. Cortes-Garcia, V. Molina-Moreno. Proposal of sustainability indicators for the waste management from the paper industry within the circular economy model, Water (Switzerland) 10 (8), (2018). 
26. F. Bassi, J. Dias. Sustainable development of small-and medium-sized enterprises in the European Union: a taxonomy of circular economy practices, Business strategy and the environment 29 (6), 2528-2541 (2020).

27. L. Kuo, B. Chang. The affecting factors of circular economy information and its impact on corporate economic sustainability-evidence from China, Sustainable production and consumption 27, 986-997 (2021).

28. H. Xu, Q. Mei, F. Shahzad, S. Liu, X. Long, J. Zhang. Untangling the impact of green finance on the enterprise green performance: a meta-analytic approach, Sustainability (Switzerland) 12 (21), 1-16 (2020).

29. M. Miralles-Quiros, J. Miralles-Quiros, I. Arraiano. Sustainability leadership and firm valuation: differences across, Benchmarking: Business strategy and the environmental, 26 (7), 1014-1028 (2017).

30. M. Yu, R. Zhao. Sustainability and firm valuation: an international investigation, International journal of accounting and information management 23 (3), 289-307 (2015).

31. A. Romanova, I. Evgeniya. Operational services management in the context of sustainable development of intelligent technologies, IOP Conf. Ser. Mater. Sci. Eng. 890, (2020). DOI: 10.1088/1757-899X/890/1/012183.

32. M. Mironova, A. Romanova, E. Ilina, I. Galeeva, D. Egorov, A. Akhmetova. Environmental activities of a petrochemical company as a sustainable factor of the city and region, IOP Conf. Ser.: Mater. Sci. Eng. 890, 012199 (2020). DOI: 10.1088/1757899X/890/1/012199. 